Academic City University College - Accra Ghana

Society for Multidisciplinary \& Advanced Research Techniques (SMART) Africa

Tony Blair Institute for Global Change

FAIR Forward - Artificial Intelligence for All - Deutsche Gesellschaft für Internationale Zusammenarbeit (GIZ) GmbH

Accra Bespoke Multidisciplinary Innovations Conference (ABMIC)

\title{
Principals' Supervision of Teachers' Instructional Strategies and Assessment Method as Correlates of Students' Academic Performance in Business Studies in Junior Secondary Schools in Taraba State, Nigeria
}

1Bambi, B. I., 2Daniel, L. \& ${ }^{3}$ Barkindo, H. M.

1,2Department of Physical Sciences Education

3Department of Vocational Education

Modibbo Adama University, Yola, Adamawa State

Emails: 1tundesluv2004@gmail.com; 2lilianswaat@gmail.com; 3hussainamaryam@gmail.com

Phones: +2348063462190; +2348039297093; +2347063179774

\section{Member Proceedings Citation Format}

Bambi, B. I., Daniel, L. \& Barkindo, H. M. (2021): Principals' Supervision of Teachers' Instructional Strategies and Assessment Method as Correlates of Students' Academic Performance in Business Studies in Junior Secondary Schools in Taraba State, Nigeria. Proceedings of the Accra Bespoke Multidisciplinary Innovations Conference. University of Ghana/Academic City University College, Accra, Ghana. December 2021. Pp 127-140. www. isteams. net/ghanabespoke2021. DOI https://doi.org/ 10.22624/AIMS/ABMIC2021-V2-P10 


\title{
Principals' Supervision of Teachers' Instructional Strategies and Assessment Method as Correlates of Students' Academic Performance in Business Studies in Junior Secondary Schools in Taraba State, Nigeria
}

\author{
Bambi, B. I., Daniel, L. \& Barkindo, H. M.
}

\begin{abstract}
This study investigated principals' instructional supervision of teachers' instructional strategies and assessment methods correlate of students' academic performance in Business Studies in junior secondary schools in Taraba State. Two research questions and two hypotheses guided the study. The study adopted correlational survey research design using a questionnaire to collect its data. The population of this study consisted of 97 Business Studies teachers. As a result of the relative small size of the population (97), census sampling technique was adopted that allowed all the population to be used. A self-developed questionnaire titled "Principal's Instructional Supervision of Business Studies Teachers' Questionnaire (PISBSTQ)" was used for data collection. The instrument was validated by 3 experts from the department of Physical Sciences Education of Modibbo Adama University, Yola and trial tested using Cronbach Alpha to get a reliability co-efficient of 0.76 . The data obtained were analysed using mean and standard deviation to answer the research questions; while Pearson's Product Moment Correlation (PPMC) was used to test the hypotheses at 0.05 level of significance. The results of the study revealed that; there is a significant high positive relationship between principal's supervision of teachers' instructional strategies and students' academic performance in business studies in junior secondary schools in Taraba state $(r=0.977, p<0.05)$; and also that there was a significant high positive relationship between principal's supervision of business studies teachers' assessment method and students' academic performance in junior secondary schools in Taraba State $(r=0.980, p<0.05)$. The study concluded that principal's instructional supervision of teachers' instructional strategies and assessment method correlates of students' academic performance in Business Studies. The study however recommended among others that respective stakeholders such as principals, school board, Nigerian Union of Teachers (NUT) should organise more often various professional development like seminars, symposium, workshops etc. for the improvement of business studies teachers' instructional strategies.
\end{abstract}

Keywords: Instructional Supervision; Instructional Strategies; Assessment Method; Academic Performance; Business Studies

\section{INTRODUCTION}

Education remains the biggest instrument for academic progress, social mobilization, political survival and effective national development of any country. The global recognition of this function of education has seen international agencies like UNESCO, UNICEF and World Bank influencing governments all over the world to double their commitments; towards making education accessible to their citizens. This has led to the introduction of Public Private Partnership (PPP) in education, where public funding is given to private schools to deliver education in countries like Philippines, India, Brazil, Ghana and South Africa (De Angelis, 2014). 
This investment in education, according to Kabir and Yahaya (2017) is a means of eradicating inequalities, poverty, hunger and social imbalance among the nations of the world. In Nigeria and especially in Taraba state, the government has continue to ensure that funds, school facilities, instructional materials, teaching personnel and a befitting learning environment are made available for schools. The Taraba state government has also continuously encouraged secondary education by adopting a social demand approach towards planning the education sector by subsidizing the Basic Education Certificate Examination (BECE) fee in the state since 2012. This situation has also helped to improve students' performance at BECE.

Performance of students is defined by Adepoju (2011) as the learning outcomes of the students which include knowledge, skills and ideas acquired and retained through students' course of studies within and outside the classroom situation. Idde (2013) in generalization of the concept stated that academic performance are parameters around which qualitative and quantitative data on the individual student, class, school or educational system are collected. This assessment is done in order to determine the quality and achievements in the educational system. Imeokparia (2018) also stated that academic performance in a school subject is symbolized by a score or marks on the achievement test. This therefore means that students' academic performance can be quantified by a measure of student's academic standing in relation to those of other students of the same age. However, there are many variables that have an influence on students' ability to perform well in both internal and external examinations. Cokley, Bernard, Cunnigham and Motoike (2011) posited that such variables include noncognitive factors such as, motivation, the teachers, family circumstances, background, previous academic performances, study skills, school facilities and many more.

Idde (2013) on the other hand suggested that factors that affect students' academic performance include the curriculum, books and materials, instructional time, school organisation, teaching and teacher education and political, social and economic factors. Although, Sunday-Piaro (2018) stated that factors that influence students' academic performance entails the teacher's handling of classroom activities such as classroom behaviours and instructional strategies. The above statements mostly direct towards the teacher's handing of instruction during classes as a major contributor to students' level of academic performance. Therefore, the study examines the place of instructional supervision as a yardstick for improving students' academic performance.

Instructional supervision as an element of educational management was described by Oyewole and Ehinola (2014) as an improvement of the teaching-learning process through a network of cooperative activities and democratic relationship of persons concerned with teaching and learning, and it is considered as an important activity to achieve an effective education system. Yusuf, Aminu and Ibrahim (2015) also opined that instructional supervision is the process of bringing about improvement in the teaching-learning process through a network of cooperative activities and democratic relationship of persons concerned with teaching and learning. It is mainly concerned with pupils learning in the classroom, and it is seen as a collaborative effort which involves a set of activities structured with the aim of improving the teaching and learning process (Archibong, 2012). Teachers, whether old or new on the job need necessary support in implementing the instructional programmes. Principals as school heads therefore, need to provide this support to teachers, they have to be involved in the implementation of instructional programmes by overseeing what teachers are doing with the students. 
In addition, Ogbuagu (2016) posited that instructional supervision aims at seeing how the teacher manages the classroom, teachers' mastery of the subject matter and lesson delivery. This implies that instructional supervision aims at making teachers to be effective during lessons. To carry out these tasks, Sule, Ameh and Egbai (2015) stated that the school head must have supervisory capacity to enforce this task and also encourage the teachers to utilize their talents when necessary so that at the end, instruction and instructional procedures can be improved.

This further means that instructional supervision is characterised by all those activities which are undertaken to help teachers maintain and improve their effectiveness in the classroom. From the foregoing, it could be said that the general consensus from the literature is that instructional supervision aims at improving teachers' instructional practices and students' learning effectively. Hence, in the context of this study, instructional supervision of school principals are narrowed to principal's supervision of business studies teachers' instructional strategies and assessment method in relation to how they correlate with students' academic performance in business studies in junior secondary schools.

According to Fayombo (2015), teaching or instructional strategies are techniques, teachers use to help students become independent and strategic learners. According to Ingrid and Reginald (2015), teachers have a sole responsibility to decide how to utilize their resources and choose strategies that will advance their students to the appropriate depth. For instance, assigning students who have low reading levels, difficult and lengthy chapters to read silently would not be an appropriate strategy because they have yet to attain acceptable levels of comprehension. Instructional strategies are therefore part of an instructional program that helps students build cognitive and problem-solving skills (Ridnouer, 2011).

These instructional strategies become learning strategies when students independently select the appropriate ones and use them effectively to accomplish tasks or meet goals (Alberta Learning, 2002). In the past, research on learning and teaching in schools has focused on the teacher's behaviour rather than the learners. As a result, educators have developed "learnercentred" or "student-centred" pedagogy that has significantly influenced our understanding of learning and teaching (Fayombo, 2014). Similarly, just as the learners learn in different ways, so also teachers teach in different ways. In fact, effective teaching requires flexibility, creativity and responsibility in order to provide an instructional environment able to respond to the learner's individual needs (Tulbure, 2012) and the attainment of good academic performance in business studies.

Assessment on the other hand is an integral part of teaching and learning in education as a whole. Mantsose (2012) stated that it covers the learning process, often referred to as summative assessment, and generates meaningful feedback to the learning process, often referred to as formative assessment. Classroom assessment according to Rahman (2018) is any planned method or strategy used in the classroom to establish the level of students' difficulties or understanding of a particular concept or idea with the purpose of helping students to succeed in learning. In essence, teachers need to create learning environments where students and teachers are active assessors during classroom instructional strategies (Volante \& Fazio, 2007). However, concrete corresponding changes in assessment practices have been lacking. Undoubtedly, teachers have been focusing merely on grades in assessment and neglecting an important component of the teaching/learning process (Mantsose, 2012). 
There is lots of evidence that there is lack in practice of classroom assessment in junior secondary schools in Taraba state. Most of the teachers are reluctant in assessing students properly; they mainly highlight on students' performance in the examination rather than emphasizing on students learning. As observed by the researchers, most business studies teachers are not oriented with effective classroom assessment strategies and for this reason, students are focused on result rather than learning. With these, there is a need for principals to supervise teacher's assessment practices in junior secondary school, if students' academic performances are to be harnessed in business studies.

Business studies, which is the focus of this study is a subject that is taught as one of the basic subjects in the junior secondary schools; which enable students to acquire personal and occupational skills (Udoukpong, Emah \& Umorem, 2012). Academic performance of students in business studies thus helps to determine the level of students' attainment of business related skills like accounting, typing and office practice at the junior secondary school stage. Business studies students' performance therefore plays an important role in measuring students potential in becoming great business entrepreneurs and manpower for the country. In the junior secondary school, students with high academic performance are regarded as students with brighter future than those that perform less. Kyoshaba (2009) opined that school teachers, principals and the quality assurance committee from the school board are usually concerned about students who do not perform well. This is because the school always lose its reputation and value, as a result of the loss in confidence with the schools' products. This may be so because, according to Heck (2009), schools are commonly evaluated using their students' academic performance, hence the need for regular supervision.

Sule, et al. (2015) stated that if teachers are not well supervised, effectiveness in instruction will be adversely affected and the instructional purposes may not be well realized. This may also lead to low quality of instruction and invariably, teachers' lack of commitment to their job which results to ineffectiveness in schools and ultimate poor students' academic performance. Although, Sunday-Piaro (2018) stated that most research that has been done on factors that influence academic achievement concentrate more on the cognitive factors while affective factors are ignored, such affective factors generally entail the teacher's handling of classroom activities such as classroom behaviours, classroom management, use of instructional materials, instructional strategies and class assessment. However, the researchers noticed significantly that there was a great dearth of literature and reviewed materials relating to students' academic achievement in business studies. It was with such keen interest that the researchers wanted to add to knowledge by studying whether there is appositive or negative relationship between principal's instructional supervision and student's academic performance in business studies, using junior secondary schools in Adamawa state.

\subsection{Problem Statement}

It is sad to note that the academic performance of students in Basic Education Certificate Examination (BECE), West Africa Senior School Certificate Examination (WASSCE) and NECO SSCE at the secondary school level is very poor all over the country in Nigeria. The hue and cry about students' academic performance in external examinations is becoming alarming. The degree of failure is giving the general public a serious concern. Couple with this, is the continuous increasing rate of examination malpractices and special centres for external examinations. These failures have no doubt made the general public to lose confidence in the ability of public schools to produce good products. 
For many years, educators and researchers have debated on which of the school variables that influence students' achievement (Fehintola, 2014; Ofeimu \& Kolawole, 2017). Sule, Ameh and Egbai (2015) opined that poor academic performances could be traced to ineffectiveness of teachers to execute their daily duties and poor instructional supervisory practices by school heads. Imeokparia (2018) in his study identified several factors that often influence students' poor academic performance such as: teachers' qualification, teaching experience, instructional materials, instructional supervision and teaching strategies. As policy-makers become more involved in school reform, greater attention is given to the role instructional supervision play on students' academic achievement. The researchers also observed that some school principals in public junior secondary schools in Taraba state have not devoted adequate time to the supervision of classroom instruction; inspection of teachers' daily lesson notes and plans; teaching methods and assessment of students' performance during and at the end of the term amongst others.

Although several attempts have been made at improving principal's instructional supervision, these efforts have not been proportionately reflected in students' overall academic performance. The researchers are indeed worried as to the level of poor academic performance in BECE especially among Business Studies' students in Taraba state. Could these factors be based on poor instructional supervision of teachers by the school principal? It was on the continued drop in academic performances in business studies that the researchers sought to empirically investigate how principals' instructional supervision of teachers' instructional strategies and assessment methods correlate of business studies students' academic performance in junior secondary schools in Taraba State, Nigeria.

Specifically, the study sought to determine how;

1. Principals' supervision of teachers' instructional strategies correlate with business studies students' academic performance in Junior Secondary Schools in Taraba State.

2. Principals' supervision of teachers' assessment method correlates with business studies students' academic performance in Junior Secondary Schools in Taraba State.

\subsection{Research Questions}

The following research questions were raised to guide the study;

1. What is the level of business studies teachers' instructional strategies in Junior Secondary Schools in Taraba State?

2. What is the level of business studies teachers' assessment methods in Junior Secondary Schools in Taraba State?

\subsection{Hypotheses}

The following null hypotheses were formulated and were tested at a level of significance of 0.05;

Ho1. There is no significant relationship between principals' supervision of teachers' instructional strategies and business studies students' academic performance in Junior Secondary Schools in Taraba State.

$\mathrm{Ho}_{2}$ : There is no significant relationship between principals' supervision of teachers' assessment method and business studies students' academic performance in Junior Secondary Schools in Taraba State. 


\section{METHODOLOGY}

The study used a correlational survey research design to guide the study. The area of the study was Taraba state. The population of this study consisted of 97 Business Studies teachers in the junior secondary schools offering business studies in Taraba state. As a result of the relative small size of the population (97), census sampling technique was adopted. According to Oleg (2019), census sampling is the technique of statistical enumeration where all members of the population are studied. The researchers therefore adopted a complete enumeration of the population since there are a total of 97 Business Studies Teachers across the state.

The study used a questionnaire as the instrument for data collection. The questionnaire was tagged "Principal's Instructional Supervision of Business Studies Teachers' Questionnaire (PISBSTQ)" and has 12 test items. The questionnaire that was used to collect data was used to answer the research questions and had different items with each item given options in a five Likert response scale letters; "VHL" for Very High Level, "HL" for High Level, "ML" for Moderate Level, "LL" for Low Level and "VLL" for Very Low Level. These letters were assigned values as $5,4,3,2$, and 1 respectively with five (5) as the highest score, standing for VHL and one (1) as the lowest score representing VLL.

To determine students' academic performance in Business Studies; the Basic Education Certificate Examination (BECE) results of Business Studies students for the past five years (i.e. 2016 - 2020) were obtained from the Ministry of Education, Jalingo, Taraba State and used to derive the mean scores for Academic Performance (Siew, Razimi, See \& Gary, 2016) for each year. This enabled the researchers to correlate it with the responses gotten from PISBSTQ.

Three research experts, one from the department of Vocational Education and two from department of Physical Sciences Education from Modibbo Adama University, Yola validated the research instrument. The instrument was trial tested to 8 principals and 24 business studies teachers in eight different junior secondary schools that were not part of the sampled population in Adamawa state. The Cronbach Alpha method was used to determine the reliability of the instruments used in the study. The overall reliability co-efficient obtained for FATAMSSQ was 0.76 ; which meant the instrument was reliable. There was a $100 \%$ return rate on the total questionnaire administered.

The research questions were answered using Mean and Standard Deviation; while Pearson's Product Moment Correlation (PPMC) was used to test the hypotheses at significance level of 0.05. The decision rule for the research questions were determined using the real limits of numbers as follows; 4.5 - 5.00 was accepted as "VHL", 3.0 - 4.49 was accepted as "HL", 2.5 - 2.99 was accepted as "ML", 1.5 - 2.49 was accepted as "LL" and 0 - 1.49 was accepted as "VLL". While the decision rule for the hypothesis was reached when the p-value exceeds the level of significance of 0.05 , the null hypotheses raised was rejected and the study concluded that the variable significantly correlate to the dependent variable. 


\section{RESULTS}

\section{Research Question 1:}

What is the level of business studies teachers' instructional strategies in Junior Secondary Schools in Taraba State?

Table 1: Mean and Standard Deviation on the level of Business Studies Teachers' Instructional Strategies in Junior Secondary Schools in Taraba State

\begin{tabular}{|c|c|c|c|c|}
\hline $\mathrm{S} / \mathrm{N}$ & $\mathrm{n}=97$ & Mean & S.D & Remark \\
\hline 1. & $\begin{array}{l}\text { Business studies teacher(s) in my school always use learner-centred } \\
\text { approaches in teaching }\end{array}$ & 3.61 & 1.08 & $\mathrm{HL}$ \\
\hline 2. & Questioning skills are effectively used by Business studies teacher(s) & 325 & 008 & MI \\
\hline 3. & Business studies teacher(s) in my school always show good subject & 3.25 & 0.98 & ML \\
\hline & 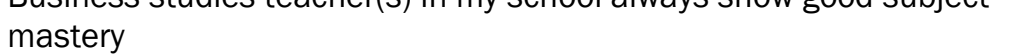 & 3.29 & 1.27 & ML \\
\hline 4. & $\begin{array}{l}\text { Lessons are usually delivered properly by Business studies teachers } \\
\text { in my school }\end{array}$ & 3.03 & 1.23 & ML \\
\hline 5. & $\begin{array}{l}\text { Teachers in my school often link business studies' lessons to real } \\
\text { life situations }\end{array}$ & 3.41 & 1.17 & ML \\
\hline 6. & $\begin{array}{l}\text { Business studies teacher(s) in my school usually carry along weak } \\
\text { students' while teaching } \\
\text { Grand Mean }\end{array}$ & $\begin{array}{l}3.60 \\
3.37\end{array}$ & $\begin{array}{l}1.08 \\
1.11\end{array}$ & $\begin{array}{l}\mathrm{HL} \\
\mathrm{ML}\end{array}$ \\
\hline
\end{tabular}

From the above, Table 1 show the grand mean score of 3.37 and standard deviation of 1.11 . This means that the level of business studies teachers' instructional strategies was at a moderate level in junior secondary schools in Taraba state.

\section{Research Question 2:}

What is the level of Business Studies Teachers' Assessment Methods in Junior Secondary Schools in Taraba State?

Table 2: Mean and Standard Deviation on the level of Business Studies Teachers' Assessment Methods in Junior Secondary Schools in Taraba State

\begin{tabular}{|c|c|c|c|c|}
\hline $\mathrm{S} / \mathrm{N}$ & ITEMS & Mean & S.D & Remark \\
\hline 1. & $\begin{array}{l}\text { Business studies teacher(s) in my school always encourage students } \\
\text { to ask questions }\end{array}$ & 3.23 & 1.39 & ML \\
\hline 2. & $\begin{array}{l}\text { Questions are always asked openly by teachers during business } \\
\text { studies classes }\end{array}$ & 3.30 & 1.05 & ML \\
\hline 3. & Teachers of Business studies in my school always give equal & & & \\
\hline & opportunities to all students to answer questions & 3.15 & 1.03 & ML \\
\hline & $\begin{array}{l}\text { Students are sometimes assessed orally during Business studies } \\
\text { classes }\end{array}$ & 3.24 & 1.34 & ML \\
\hline 5. & Business studies teacher(s) in my school always assess students' & & & \\
\hline & knowledge through individual work & 3.38 & 1.18 & ML \\
\hline 6. & $\begin{array}{l}\text { Group work is an assessment method, often used by Business studies } \\
\text { teachers in my school to assess students }\end{array}$ & 3.12 & 136 & 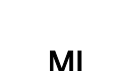 \\
\hline & Grand Mean & 3.24 & 1.19 & $\mathrm{ML}$ \\
\hline
\end{tabular}


From the above, Table 2 shows the grand mean score of 3.24 and standard deviation of 1.19. This means that the level of principals' instructional supervision of business studies teachers' assessment methods was at a moderate level in junior secondary schools in Taraba state.

\section{Research Hypotheses:}

Ho1. There is no significant relationship between principals' supervision of teachers' instructional strategies and business studies students' academic performance in Junior Secondary Schools in Taraba State.

Table 3: Pearson's Product Moment Correlation Coefficient (PPMC) analysis on Principals' Supervision of Teachers' Instructional Strategies and Business Studies Students' Academic Performance

\begin{tabular}{ccccccr}
\hline Variables & $\mathrm{n}$ & $\overline{\mathrm{X}}$ & $\mathrm{SD}$ & $\boldsymbol{r}$ & $\mathrm{p}$-value & Decision \\
\hline Instructional Strategies & 97 & 3.37 & 1.11 & & \multirow{2}{*}{0.00} & Reject \\
& & & & 0.977 & 0.00 & \\
Students' Academic performance & 97 & 3.11 & 1.05 & & & \\
\hline Key: $X$ = Mean; S.D = Standard Deviation; $r=$ PPMC & & &
\end{tabular}

Table 3 shows the correlational analysis of principals' supervision of business studies teachers' instructional strategies and students' academic performance as, $r=0.977, p<0.05$. With this result, the null hypothesis $(\mathrm{Ho})$ is thus rejected. This implies that there was a significant high positive relationship between principal's supervision of business studies teachers' instructional strategies and students' academic performance in junior secondary schools in Taraba State.

Ho2: There is no significant relationship between principals' supervision of teachers' assessment method and business studies students' academic performance in Junior Secondary Schools in Taraba State.

Table 4: Pearson's Product Moment Correlation Coefficient (PPMC) analysis on Principals' Supervision of Teachers' Assessment Method and Business Studies Students' Academic Performance

\begin{tabular}{ccccccr}
\hline Variables & $\mathrm{n}$ & $\overline{\mathrm{X}}$ & $\mathrm{SD}$ & $\boldsymbol{r}$ & $\mathrm{p}$-value & Decision \\
\hline Assessment Method & 97 & 3.24 & 1.19 & & & \\
& & & & 0.980 & 0.00 & Reject \\
Students' Academic performance & 97 & 3.11 & 1.05 & & & \\
\hline
\end{tabular}

Key: $\bar{X}=$ Mean; S.D $=$ Standard Deviation; $r=$ PPMC

Table 4 shows the correlational analysis of principals' supervision of business studies teachers' assessment method and students' academic performance as, $r=0.980, p<0.05$. With this result, the null hypothesis $(\mathrm{Ho})$ is thus rejected. This implies that there was a significant high positive relationship between principal's supervision of business studies teachers' assessment method and students' academic performance in junior secondary schools in Taraba State 


\subsection{Major Findings of the Study}

The major findings of the study are as follows;

1. The level of business studies teachers' instructional strategies was at a moderate level in junior secondary schools in Taraba state (with a grand mean of 3.37).

2. The level of business studies teachers' assessment methods was at a moderate level in junior secondary schools in Taraba state (with a grand mean of 3.24).

3. There was a significant high positive relationship between principal's supervision of business studies teachers' instructional strategies and students' academic performance in junior secondary schools in Taraba State $(r=0.977, p<0.05)$.

4. There was a significant high positive relationship between principal's supervision of business studies teachers' assessment method and students' academic performance in junior secondary schools in Taraba State $(r=0.980, p<0.05)$.

\section{DISCUSSION OF FINDINGS}

This study found out that, the level of principals' instructional supervision of business studies teachers' instructional strategies was at a moderate level in junior secondary schools in Taraba state (with a grand mean of 3.37). This finding concurred with Hoge (2016); John (2016) and Ganyaupfu (2013) studies, who found out that teachers used different instructional strategies to minimize the challenges of attaining lesson objectives in senior secondary schools. This thus allows them to function to their own capacity. Although, the findings disagree with that of Eze's (2011) study that instructional strategies among schools studied was one-directional that is solemnly focused on teacher centre; thereby not catering enough for students' learning effectiveness during the teaching and learning process. Hypothesis 1, which was rejected, as there was a significant high positive relationship between principal's supervision of business studies teachers' instructional strategies and students' academic performance in junior secondary schools in Taraba State $(r=0.977, p<0.05)$.

The finding was in line with Hoge (2016) and John (2016) studies who found out that there was a significant relationship between teachers' instructional strategies students' academic performance in both internal and external examinations. The finding however disagrees with that of Eze's (2011) study that there was also no significant relationship between teacher experience and instructional strategies and students' achievement in mathematics. However, from the results obtained from the research question and correlation; it could be deduced that a carefully aligned curriculum in business studies must be taught with different instructional strategies that will assist teachers to have positive impacts on students' academic performance.

This study also found that; the level of principals' instructional supervision of business studies teachers' assessment methods was at a moderate level in junior secondary schools in Taraba state (with a grand mean of 3.24). This finding concurred with Rahman (2018); Siarova, Sternadel, Mašidlauskaitè (2017) and Frey and Schmitt's (2010) findings that revealed that teachers' assessment methods were at average level; as teachers' current practice of classroom assessment was to only assess students learning achievement and they followed traditional methods to assess students. The results of this study further revealed that the dominated assessment activities of teachers were oral questioning and very few students take part in the assessment activities by answering the questions. The classroom questions are basically focused very specific responses and encouraged rote learning; even students' didn't get enough time for thinking and answering the questions. 
Frey and Schmitt's (2010) study also showed that teachers do not diversify with their assessment strategies. Also, there was a significant high positive relationship between principal's supervision of business studies teachers' assessment method and students' academic performance in junior secondary schools in Taraba State $(r=0.980, p<0.05)$. The finding was in line with Rahman (2018) study who found out that there was a statistically significant relationship between the dependent variable (teachers' assessment method) and students' academic performance. Therefore the study suggests changing current practices by using different assessment strategies

\section{CONCLUSION}

Based on the findings of this study, it was concluded that the variables of principals' instructional supervision (teacher's instructional strategies and assessment method) have significant high positive relationship on business studies students' academic performance in junior secondary schools in Taraba state.

The study however recommends the following;

1. Respective stakeholders such as principals, school board, Nigerian Union of Teachers (NUT) should organise more often various professional development like seminars, symposium, workshops etc. for the improvement of business studies teachers' instructional strategies.

2. Business studies teachers need to diversify their assessment strategies that will focus more on assessment for learning such as students' self and peer assessment to ensure effective teaching-learning of business studies.

3. The school board should facilitate conditions in which principals can be regularly trained in instructional supervisory skills; so that they can also empower teachers to use different instructional practices in their classroom teaching for the improvement of students' academic performance in business studies. 


\section{REFERENCES}

1. Adepoju, T. L. (2011). A study of secondary school students' academic performance at the senior school certificate examinations and implications for educational planning and policy in Nigeria. African Research Review, 5(6), 314 - 333.

2. Alberta Learning (2002). Health and Life Skills Guide to Implementation (K-9): Instructional Strategies. Canada: Alberta Publications, 67 - 114. Retrieved from: https://education.alberta.ca/media/352984/is.pdf

3. Archibong, F. I. (2012). Instructional supervision in the administration of secondary education: A panacea for quality assurance. European Scientific Journal, 8(13), 61 70.

4. Cokley, K. O., Bernard, M., Cunnigham, D. \& Motoike, J. (2011). A psychometric investigation of the academic motivation scale using a United States sample. Measurement and Evaluation in Counselling and Development, 34(2), 109 - 119.

5. De Angelis, R. (2014). Quality in Indian education: Public-private partnerships and grantin-Aid schools. Educate, 14(2), 13 - 28.

6. Eze, P. H. (2011). The relationship between instructional strategies/teacher methodologies and student performance and its implication for school leaders. ETD Collection for AUC Robert W. Woodruff Library. Paper 232.

7. Fayombo, G. A. (2014). Promoting student engagement and learning outcomes in psychology course through technology infused learner-centred strategies. In F. Veiga (Ed.). Students' engagement in school. International Perspectives of Psychology and Education, Lisboa. 687 - 703.

8. Fayombo, G. A. (2015). Learning styles, teaching strategies and academic achievement among some psychology undergraduates in Barbados. Caribbean Educational Research Journal. 3(2), 46 - 61.

9. Federal Government of Nigeria, FRN, (2013). National policy on education. Abuja: NERDC Press.

10. Fehintola, J. O. (2014). Teachers' characteristics as correlates of students' academic performance among secondary school students in Saki-west Local Government Area of Oyo State. Journal of Educational and Social Research, 4(6), 459 - 468.

11. Frey, B. B. \& Schmitt, V. L. (2010). Teachers' classroom assessment practices. Middle Grades Research Journal, 5(3), 107 - 117.

12. Ganyaupfu, E. M. (2013). Teaching methods and students' academic performance, pc training and business college, South Africa. International Journal of Humanities and Social Science Invention, 2(9), 29 - 35.

13. Hoge, D. M. (2016). The relationship between teachers' instructional practices, professional development, and student achievement. Master's Thesis: University of Nebraska.

14. Idde, G. (2013). The effect of teachers' workload on students' academic performance in community secondary schools: A study of Mbeya city Tanzania. Master's Thesis: University of Tanzania.

15. Imeokparia. P. O. (2018). Influence of environmental factors on academic performance of business studies' students in upper basic level in Edo State. Journal of Education and Practice, 9(24), 22 - 28. 
16. Ingrid, A. T. \& Reginald, L. G. (2015). Using instructional strategies to enhance student achievement. National Forum of Teacher Education Journal, 25(3), 1 - 17.

17. John, L. T. (2016). Role of instructional materials in academic performance in community secondary schools in Rombo District. Master's Thesis: University of Tanzania.

18. Kabir, F. S. \& Yahaya, A. (2017). Explorative study on the adoption and utilization of mobile devices for academic activities amongst distance education students in Nigeria. Multidisciplinary Journal of Science, Technology and Vocational Education, 5(1), 117 124.

19. Kyoshaba, M. (2009). Factors affecting academic performance of undergraduate at Uganda Christian University. Master's thesis: Uganda Christian University.

20. Mantsose, J. S. (2012). An investigation of the challenges affecting teachers' classroom assessment practices. Ph.D. Thesis: University of South Africa.

21. Ofeimu, J. \& Kolawole, B. O. (2017). Teacher quality as determinant of students' academic performance in secondary schools in Edo South Senatorial District of Nigeria. British Journal of Education, 5(13), 19 - 30.

22. Ogbuagu, C. A. (2016). Communication as a tool in supervision and inspection. In S. O. Oluwuo, V. C. Onyeike and J. D. Asodike (eds). Supervision and inspection in schools for productivity: Emerging perspectives. Port Harcourt: Pearl Digital Press, 206 - 225.

23. Oleg, C. (2019). Use of sampling in the census. Regional workshop on the operational guidelines of the WCA 20220, Amman, Jordan, 1 - 4th April, 2019.

24. Oyewole, B. K. \& Ehinola, G. B. (2014). Relevance of instructional supervision in the achievement of effective learning in Nigerian secondary schools. Global Journal of Commerce and Management Perspective, 3(3), 88 - 92.

25. Rahman, M. M. (2018). Exploring teachers' practices of classroom assessment in secondary science classes in Bangladesh. Journal of Education and Learning, 7(4), 274 $-283$.

26. Ridnouer, K. (2011). Everyday engagement: Making students and parents your partners in learning. Retrieved from http://web.ebscohost.com.ezproxy.memphis.edu/ehost/ebookviewer/ebook/nlebk 1 1732 AN?sid=40593f70-0e97-4c66-bca7-c2c03fb3fc9f@sessionmgr111\&vid=3

27. Siarova, H., Sternadel, D. \& Mašidlauskaitè, R. (2017). Assessment practices for 21st century learning: review of evidence, NESET II report. Luxembourg: European Union Publications.

28. Siew, F. N., Razimi, Z., See, M. L. \& Gary, J. C. (2016). A study of time use and academic achievement among secondary school students in the state of Kelantan, Malaysia. International Journal of Adolescence and Youth. 21(4), 433 - 448.

29. Sule, M. A., Ameh, E. \& Egbai, M. E. (2015). Instructional supervisory practices and teachers' role effective in public secondary schools in Calabar South Local Government Area of Cross River State, Nigeria. Journal of Education and Practices, 6(23), 43 - 47.

30. Sunday-Piaro, M. (2018). Classroom management and students' academic performance in public secondary schools in Rivers State. International Journal of Scientific Research in Education, 11(5), 940 - 963.

31. Tulbure, C. (2012). Investigating the relationships between teaching strategies and learning styles in higher education. Acta Didactica Napocensia, 5(1), 65 - 74.

32. Udoukpong, B. E., Emah, I. E. \& Umoren, S. E. (2012). Business studies academic performance differences of secondary school juniors in Akwa Ibom State of Nigeria. International Education Studies, 5(2), 35 - 43. 
33. Volante, L. \& Fazio, X. (2007). Exploring teacher candidates' assessment literacy: implications for teacher education reform and professional development. Canadian Journal of Education, 30(3), 749 - 770.

34. Yusuf, M., Aminu, Y. \& Ibrahim, M. M. (2015). Relevance of instructional supervision in the effective teaching and learning in Nigeria universal basic education school system. IOSR Journal of Research \& Method in Education (IOSR-JRME), 5(4), 22 - 26. 